\title{
SISTEM APLIKASI PENGOLAHAN DATA BAHAN BAKU DAN BAHAN JADI PADA PABRIK PENGOLAHAN PUPUK ORGANIK CV. AJ PRATAMA GROUP AIR JOMAN MENGGUNAKAN METODE JUST IN TIME (JIT)
}

\author{
Wanayumini ${ }^{1}$, M. Ari Iskandar ${ }^{2}$ \\ Universitas Asahan: Jl. Ahmad Yani Kisaran Telp. (0623) 456222 \\ Program Studi Teknik Informatika, Fakultas Teknik Una, Kisaran Sumatera Utara \\ wanayumini@gmail.com ${ }^{1}$, iskandarari123@gmail.com²
}

\begin{abstract}
Abstrak - Tujuan penulisan Penelitian ini untuk mepermudah pengguna dalam mengelola data bahan baku dan bahan jadi untuk memperoleh laba atau keuntungan dalam melakukan proses produksi. Metode yang ada saat ini masih manual, dimana terjadi kesalahan dalam menghitung jumlah bahan baku yang dibutuhkan, sehingga sering terjadi kerugian dalam setiap proses produksinya. Aplikasi ini di disain dengan menggunakan metode Just In Time (JIT) atau metode tepat waktu dimana pengguna hanya akan membeli bahan baku sesuai dengan jumlah kebutuhan yang diperlukan. Sehingga pengguna akan lebih mudah menghemat biaya produksi dikarenakan tidak akan takut kelebihan stok bahan baku, dan ini juga akan menghemat ruang penyimpanan di dalam gudang. Jadi dapat di simpulkan bahwa aplikasi ini dapat menggantikan metode yang lama. Sehingga dalam setiap proses produksinya dilakukan dengan tepat dan memperoleh laba atau keuntungan yang lebih besar lagi. Kelemahan aplikasi ini desainnya masih sangat sederhana.
\end{abstract}

Kata Kunci - Visual Basic.Net 2010, Sistem Aplikasi Pengolahan Data Bahan Baku dan Bahan Jadi, Metode Just In Time (JIT).

\begin{abstract}
The purpose of this thesis is to facilitate users in managing data on raw materials and finished materials to obtain profits or profits in carrying out the production process. The current method is still manual, where there is an error in calculating the amount of raw materials needed, so that losses often occur in each production process. This application is designed using the Just In Time (JIT) method or a timely method where users will only buy raw materials according to the number of needs needed. So that users will be easier to save on production costs because they will not be afraid of excess stock of raw materials, and this will also save storage space in the warehouse. So it can be concluded that this application can replace the old method. So that in each production process it is carried out properly and gets a bigger profit or profit. The weakness of this application is that the design is still very simple.
\end{abstract}

Keywords - Visual Basic.Net 2010, Sistem Aplikasi Pengolahan Data Bahan Baku dan Bahan Jadi, Metode Just In Time (JIT)

\section{PENDAHULUAN}

\section{A. Latar Belakang}

Seiring dengan berkembangnya dunia perindustrian dan semakin banyaknya permintaan dan kebutuhan, maka sangat penting untuk mempelajari bagaimana cara mengendalikan suatu produk untuk dapat terorganisir data-data produksi perusahaan. Dengan adanya pengendalian yang merupakan salah satu faktor dominan untuk dapat mencapai sukses dalam proses produksi maupun target pemasaran yang di inginkan suatu perusahaan.

CV. AJ Pratama Group yang terletak di Desa Subur Dusun III Kecamatan Air Joman ini adalah perusahaan yang bergerak di bidang pembuatan pupuk organik. Pada CV. AJ Pratama Group, pengolahan datanya masih dicatat di dalam buku atau masih secara manual. Sehingga sangat rentan untuk kehilangan data-data perusahaan, serta waktu produksi sering meleset dari jadwal yang ditentukan sehingga mengakibatkan laba atau keuntungnnya sedikit berkurang.

Sistem aplikasi pengolahan data adalah suatu kestauan yang saling berhubungan atau terintegrasi untuk membentuk suatu sistem antara data, perangkat keras, perangkat lunak, prosedur pengolahan dan tenaga pelaksana. Sistem pengolahan data menghasilkan output / informasi yang akan digunakan oleh perorangan atau kelompok, baik di dalam maupun diluar perusahaan. Adapun salah satu metode yang sering digunakan dalam pembuatan sistem aplikasi pengolahan data yaitu metode JIT (Just In Time). Metode JIT (Just In Time) adalah metode yang pada prinsipnya hanya memproduksi jenis barang yang diminta sejumlah yang diperlukan oleh 
konsumen, yang bertujuan untuk meningkatkan laba dan menghemat biaya agar lebih efisien.

Sehubungan dengan hal terssebut di atas, maka dapat di jadikan suatu pertimbangan atau tolak ukur bagi penulis dalam pembuatan Penelitian dengan judul "Sistem Aplikasi Pengolahan Data Bahan Baku dan Bahan Jadi pada Pabrik Pengolahan Pupuk Organik CV. AJ Pratama Group Air Joman Menggunakan Metode Just In Time (JIT)"

\section{B. Rumusan Masalah}

Adapun masalah yang dapat dirumuskan dalam Penelitian ini antara lain adalah sebagai berikut:

1. Bagaimana merancang aplikasi Pengolahan Data Bahan Baku dan Bahan Jadi pada Pabrik Pengolahan Pupuk Organik CV. AJ Pratama Group?

2. Bagaimana pengolahan data bahan baku dan bahan jadi pupuk yang berjalan pada pabrik pengolahan pupuk CV. AJ Patama Group?

3. Bagaimana menerapkan metode Just In Time (JIT) dalam perhitungan stok barang dan waktu produksi yang lebih efisien?

\section{Batasan Masalah}

Agar penulisan Penelitian ini lebih terarah dan tujuan yang diharapkan dapat tercapai, penulis menentukan batasan-batasan masalahnya sebagai berikut:

1. Perancangan aplikasi ini hanya membahas masalah tentang Pengolahan Data Bahan Baku dan Bahan Jadi pada Pabrik Pengolahan Pupuk Organik CV. AJ Pratama Group.

2. Aplikasi ini dirancang dengan menggunakan bahasa pemrograman berbasis Visual Studio Ultimate 2010 dan menggunakan database MySQL Server 2008.

3. Dan penerapan metode Just In Time (JIT) digunakan untuk mengoptimalkan pembelian bahan baku dan mempersingkat efisiensi waktu produksi yang dapat menekan biaya biaya persediaan.

D. Tujuan Penelitian berikut:

Adapun tujuan dari penelitian ini adalah sebagai

1. Menganalisa sistem yang ada pada Pabrik CV.AJ Pratama Group tentang perhitungan stok bahan baku dan bahan jadi, apakah sudah seuai sistem komputerisasi yang dipakai

2. Meningkatkan perkembangan ekonomi dan cara kerja dalam ketepatan dan kecepatan proses penjualan dengan sistem bukan manual.
3. Dapat memasarkan produk pupuk organic sehingga dapat diterima di masyarakat sebagai pengganti pupuk kimia.

\section{TINJAUAN PUSTAKA}

A. Sistem

Sistem didefenisikan sebagai sekumpulan prosedur yang saling berkaitan dan saling terhubung untuk melakukan suatu tugas bersama-sama (I Putu Agus Eka Pratama, 2014:7). Sistem pada dasarnya adalah sekelompok unsur yang erat hubungannya satu dengan lainya, yang berfungsi bersama-sama untuk mencapai tujuan tertentu. Norman L. Enger menyatakan bahwa suatu sistem dapat terdiri atas kegiatan-kegiatan yang berhubungan guna mencapai tujuan-tujuan perusahaan seperti pengendalian inventaris atau penjadwalan produksi. Sedangkan Prof. Dr. Mr. S. Prajudi Atmosudirdjo menyatakan bahwa suatu sistem terdiri atas objek-objek atau unsur-unsur atau komponen-komponen yang berkaitan dan berhubungan satu sama lainya sedemikian rupa sehingga unsur-unsur tersebut merupakan suatu kesatuan pemrosesan atau pengolahan yang tertentu (Tata Sutabri, 2012:7).

\section{B. Karakteristik Sistem}

Model umum sebuah sistem terdiri dari input, proses, dan output. Hal merupakan konsep sebuah sistem yang sangat sederhana mengingat sebuah sistem dapat mempunyai beberapa masukan dan keluaran sekaligus.Selain itu sebuah sistem juga memiliki karakteristik atau sifat-sifat tertentu, yang mencirikan bahwa hal tersebut bisa dikatakan sebagai suatu sistem. Adapun karakteristik yang dimaksud adalah sebagai berikut (Tata Sutabri, 2012:13):

1. Komponen Sistem (Components)

Suatu sistem terdiri dari sejumlah komponen yang saling berintraksi, yang bekerja sama memebentuk satu kesatuan. Komponenkomponen sistem tersebut dapat berupa suatu bentuk subsistem.

2. Batasan Sistem (Boundary)

Ruang lingkup sistem merupakan daerah yang membatasi antara sistem dengan sistem lainya atau sistem dengan lingkungan luar.

3. Lingkungan Luar Sistem (Environment)

Bentuk apapun yang ada diluar ruang lingkup atau batasan sistem yang mempengaruhi operasi sistem tersebut disebut dengan dengan lingkungan luar sistem.

4. Penghubung Sistem (Interface)

Penghubung merupakan media penghubung antara satu subsistem dengan satu subsistem yang lainnya. Melalui penghubung ini 
memungkinkan sumber-sumber daya mengalir dari satu subsistem ke subsistem yang lainnya. Keluaran (output) dari satu subsistem akan menjadi masukan (input) untuk subsistem yang lainnya dengan melalui penghubung. Dengan penghubung satu subsistem dapat berinteraksi dengan subsistem yang lainnya membentuk satu kesatuan.

5. Masukan Sistem

Masukan adalah energi yang dimasukan kedalam sistem. Masukan dapat berupa masukan perawatan (maintenance input) dan masukan sinyal (signal input). Maintenance input adalah energi yang dimasukan supaya sistem tersebut dapat beroperasi. Signal input adalah energi yang diproses untuk didapatkan keluaran.

6. Keluran Sistem

Keluaran adalah hasil dari energi yang diolah dan diklasifikasikan menjadi keluaran yang berguna dan sisa pembuangan. Keluaran dapat berupa masukan untuk subsistem yang lain atau kepada supra sistem. Misalnya untuk sistem komputer, panas yang dihasilkan adalah keluaran yang tidak berguna merupakan hasil sisa pembuangan, sedang informasi adalah keluaran yang dibutuhkan.

7. Pengolah Sistem

Suatu sistem dapat mempunyai suatu bagian pengolah atau sistem itu sendiri sebagai pengolahnya. Pengolah yang akan merubah masukan menjadi keluaran.

8. Sasaran Sistem

Suatu sistem pasti mempunyai tujuan (goal) atau sasaran (objective). Kalau suatu sistem tidak mempunyai sasaran, maka operasi sistem tidak akan ada gunanya. Sasaran dari system sangat menentukan sekali masukan yang dibutuhkan sistem dan keluaran yang akan dihasilkan sistem. Suatu sistem dikatakan berhasil bila mengenai sasaran atau tujuannya.

\section{Aplikasi}

Aplikasi adalah program siap pakai yang dapat digunakan untuk menjalankan perintah-perintah dari pengguna aplikasi tersebut dengan tujuan mendapatkan hasil yang lebih akurat sesuai dengan tujuan pembuatan aplikasi tersebut. Aplikasi mempunyai arti, yaitu pemecahan masalah yang menggunakan salah satu tehnik pemrosesan data aplikasi yang biasanya berpacu pada sebuah komputasi yang diinginkan atau diharapkan maupun pemrosesan data yang diharapkan. Pengertian aplikasi secara umum adalah alat terapan yang difungsikan secara khusus dan terpadu sesuai kemampuan yang dimilikinya selain itu aplikasi merupakan suatu perangkat komputer yang siap pakai bagi user (Hasan Abdurahman, 2014).

\section{Data}

Menurut Kadir (2013), data adalah dePenelitian tentang benda, kejadian, aktifitas, dan transaksi, yang tidak mempuyai makna atau tidak berpengaruh secara langsung kepada pemakai. Data menjadi bahan dalam suatu proses pengolahan data. Oleh karena itu, suatu data belum dapat berbicara banyak sebelum diolah lebih lanjut. Sedangkan menurut Sutarman (2012), data adalah fakta dari suatu pernyataan yang berasal dari kenyataan, dimana pernyataan tersebut merupakan hasil pengukuran dan pengamatan.

\section{E. Bahan Baku}

Berdasarkan pengertian secara umum, perbedaan arti kata antara bahan baku dan mentah dapat diartikan sebagai berikut. Pengertian secara umum dari istilah bahan mentah dapat mempunyai arti sebagai sebuah bahan dasar yang bisa berasal dari berbagai tempat, yang mana bahan tersebut dapat digunakan untuk diolah dengan suatu proses tertentu ke dalam bentuk lain yang berbeda wujud dari bentuk aslinya. Sedangkan pengertian secara umum mengenai bahan baku merupakan bahan mentah yang menjadi dasar pembuatan suatu produk yang mana bahan tersebut dapat diolah melalui proses tertentu untuk dijadikan wujud yang lain.

Berdasarkan dari pengertian antara bahan mentah dan bahan baku di atas terdapat beberapa contoh wujud dari istilah bahan mentah beberapa di antaranya adalah bijih perak, yang mempunyai arti penting didalam industri pembuatan perak, contoh yanng lainnya adalah gandum yang mana biji dari tumbuhan tersebut bila dikeringkan dan di olah dapat menghasilkan tepung yang mana biji gandum ini sangat berguna bagi industri penghasil tepung. Sedangkan berdasarkan pengertian umum contoh wujud dari istilah bahan baku diantaranya adalah, perak dan kompor yang berguna sebagai bahan dasar bagi industri penghasil kerajinan dari perak, seperti anting - anting, kalung dan bingkai foto yang bisa di gunakan untuk hiasan dinding, contoh yang lainnya adalah tepung, margarin, telur, dan gula, yang sangat berguna sebagai bahan baku pembuatan roti, karena sifat dari tepung yang bisa mengikat emulsi dari udara yang terkandung di dalam adonan roti setelah adonan dasar di mixer, apabila adonan tersebut tidak di beri tepung, maka rasanya akan lebih berat dan eneq serta tidak bisa tahan lama, tetapi berbeda bila di kasih dengan campuran tepung, roti yang dihasilkan akan lebih terasa kenyal dan mempunyai bentuk yang lebih bagus dan bisa lebih lama disimpan. Dikutip dari laman 
(https://erwinnote.wordpress.com/2011/09/21/definisidan-jenis-bahan-baku/)

\section{F. Persediaan}

Menurut Dewi Sawitri (2015), persediaan dapat diartikan sebagai barang-barangyang disimpan untuk digunakan atau dijual pada masa atau periode yang akandatang. Sedangkan menurut Rohayah (2016), persediaan adalah barang yang di beli untuk dijual kembali. Misalnya, barang yang di beli pengecer untuk di jual kembali.

\section{G. Pupuk Organik}

Usaha yang dilakukan untuk memperbaiki kesuburan tanah adalah dengan melakukan pemupukan menggunakan pupuk organik. Kandungan unsur hara dalam pupuk kandang tidak terlalu tinggi, tetapi jenis pupuk ini mempunyai lain yaitu dapat memperbaiki sifat-sifat fisik tanah seperti permeabilitas tanah, porositas tanah, struktur tanah, daya menahan air dan kation-kation tanah (Ida Syamsu Raida, 2013).

\section{H. Just In Time (JIT)}

Menurut Wijaksono dalam jurnal yang dibuat oleh Azhar Madianto, Dzulkirom AR dan Dwiatmanto (2016), "Just In Time (JIT) adalah suatu filosofi bisnis yang khusus membahas bagaimana mengurangi waktu produksi baik dalam proses manufaktur maupun proses non-manufaktur. Selain itu, dijelaskan pula oleh Hamming dalam jurnal yang sama bahwa JIT (Just In Time) merupakan strategi pengaturan persediaan yang menerapkan konsep untuk meningkatkan rasio laba terhadap investasi dari sebuah usaha bisnis dengan mengurangi persediaan dan biaya-biaya yang terkait dengan persediaan.

\section{Unified Modeling Language (UML)}

Menurut Deni Mahdiana (2013), “Unified Modeling Language (UML) adalah salah satu alat bantu yang sangat handal di dunia pengembangan sistem yang berorientasi obyek". Sedangkan menurut Shalahuddin dan Rosa dalam jurnal yang ditulis oleh Winda Aprianti dan Umi Maliha (2016), "Unified Modeling Language (UML) adalah standarisasi bahasa permodelan untuk membangun perangkat lunak yang di bangun dengan menggunakan teknik pemrograman berorientasi objek"..

\section{J. Konsep Dasar Rekayasa Perangkat Lunak}

Menurut Yuhendra, M.T, Dr. Eng, Riza Eko Yulianto (2015), yang dikutip dari Janner Simarmata. Rekayasa merupakan penerapan ilmu dan teknologi untuk menyelesaikan permasalahan manusia. Sedangkan rekayasa perangkat lunak atau RPL atau
Software engineering adalah satu bidang yang mendalami cara-cara pengembangan perangkat lunak termasuk pembuatan, pemeliharaan, manajemen organisasi pengembangan perangkat lunak, dan sebagainya.

\section{K. MySQL (My Strukture Query Language)}

MySQL merupakan turunan salah satu konsep utama dalam database yaitu, SQL (Structured Query Language). SQL merupakan sebuah konsep pengoperasian database, terutama untuk pemilihan/seleksi dan pemasukan data, yang memungkinkan pengoperasian data dikerjakan dengan mudah secara otomatis (Rika Idmayanti, 2014). Menurut Alhadi Saputra (2012), yang dikutip dari Allen G. Tailor MySQL merupakan software database open source yang paling populer di dunia, dimana saat ini digunakan lebih dari 100 juta penggunadi seluruh dunia. Dengan kehandalan, kecepatan dan kemudahan penggunaannya, MySQL menjadi pilihan utama bagi banyak pengembang software dan Aplikasi baik di platform web maupun desktop. Pengguna MySQL tidak hanya sebatas pengguna perseorangan maupun perusahaan kecil, namun perusahaan seperti Yahoo!, Alcatel-Lucent, Google, Nokia, Youtube, Wordpress dan Facebook juga merupakan pengguna MySQL.

\section{Database}

Menurut Rajib Abi Bakri (2013), database adalah suatu sistem menyusun dan mengelola hasil record menggunakan komputer untuk menyimpan atau merekam serta memelihara data operasional lengkap sehingga mampu menyediakan informasi yang optimal yang diperlukan pemakai untuk proses mengambil keputusan. Sebenarnya semua data dalam komputer disimpan dalam bentuk biner, tipe data ini didesain untuk menyimpan digit biner secara sekuensial.

\section{Visual Basic.NET 2010}

Menurut Nurullah (2012), Basic adalah salah satu bahasa pemograman dasar di dalam komputer untuk membuat aplikasi, basic adalah kependekan dari kata-kata
a. B
(Beginner's)
b. A
(All-Purpose)
c. $\mathrm{S}$
(Symbol)
d. I
(instruction)
e. $\mathrm{C}$
(Code)

Bahasa ini pertama kali muncul pada tahun 1960 dan diperkenalkan oleh Darmouth college, bahasa ini mengalami perkembangan yang pesat sekali sehingga di Tahun 1970 digunakan oleh bill gates dan paul allen untuk mengontrol microcomputer alltair, kemudian 
bahasa basic digunakan para pengembang software lain dengan nama berbeda, namun aturan dan bahasa yang digunakan adalah sama, seperti: GW-Basic, Qbasic, Quick basic dan sebagainya.

\section{METODE PENELITIAN}

Metode dalam perancangan aplikasi penelitiani ini, penulis menggunakan metode observasi berupa pengumpulan data dari sumber-sumber yang berkaitan, yang nantinya digunakan untuk memperoleh data-data yang dibutuhkan dalam pembuatan aplikasi pengolahan data, sehingga yang nantinya aplikasi yang digunakan benar-benar bermanfaat baik bagi pengguna sendiri maupun orang lain.

A. Bahan Penelitian

Bahan penelitian diambil dari sumber data primer dan sekunder.

1. Data primer diteliti secara langsung dari perpustakaan dengan metode wawancara dan observasi di lapangan, antara lain :

a. Data buku, dari data-data buku diperoleh atribut untuk disimpan dalam record yang berkaitan dengan buku yaitu judul buku, pengarang, penerbit, edisi buku, jenis buku, jumlah halaman, jumlah eksemplar dan tahun terbit.

b. Data dari Pabrik CV.Aj Pratama Group, meliputi data jumlah bahan baku, data pemesanan bahan baku dan bahan jadi dan data penjualan bahan jadi yang akan digunakan untuk melengkapi field pada storage anggota.

2. Data sekunder meliputi data - data yang diperoleh dari buku literatur, studi pustaka mengenai perhitungan, pengolahan data, Microsoft SQL Server Management Studio, dan bahasa pemrograman Microsoft Visual Studio Ultimate 2010.

\section{ANALISA DAN PEMBAHASAN}

A. Analisa Masalah

Dalam melakukan pembangunan aplikasi ini terdapat beberapa masalah dan faktor penting yang perlu diperhatikan yaitu mengenai permasalahan penentuan waktu tunggu yang dibutuhkan dalam mengolah bahan mentah menjadi pupuk siap pakai dan menghitung keuntungan dalam pencapaian hasil produk. Hasil analisa ini akan dijadikan sebagian acuan dalam pembangunan aplikasi.

\section{B. Analisa Metode Just In Time (JIT)}

Untuk mengukur apakah biaya yang tidak bernilai tambah telah dihilangkan atau diminimumkan pada setiap tahap produksi, kita perlu menghitung efisiensi siklusnya.

Biaya Modal :

Gaji Karyawan: Rp 20.000,00 x $10=$ Rp 200.000,00

Harga Bahan Baku: Rp 300.000,00/300 Kg

Bahan jadi Total biaya produksi/Kg: Rp 500.000,00

Harga jual :

Harga jual pasaran: Rp. 3.000.000,00/300 kg bahan jadi

Laba/keuntungan perusahaan: harga jual passaran modal awal : Rp. $3.000 .000,00-$ rp 500.000,00 = rp 2.500.000,00

Waktu yang diperlukan : 10 hari kerja

Jadi keuntungan perusahaan perhari adalah : rp $2.500 .000,00 / 10=\operatorname{rp} 250.000,00$

Jadi metode ini lebih menguntungkan dibandingkan dengan metode lama yang keuntungannya tidak lebih dari rp 150.000,00/ hari.

C. Perancangan UML

Untuk lebih memperjelas tentang gambaran sistem maka penulis membuat UML (Unified Modeling Language) dengan beberapa tipe yaitu sebagai berikut.

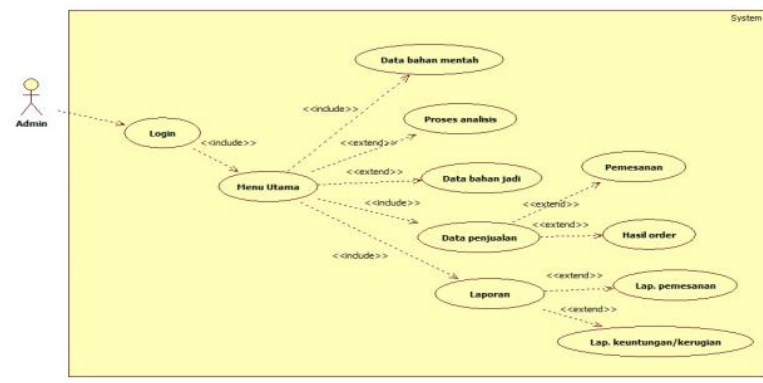

Gambar 4.1 Use Case Diagram

D. Class Diagram

Class diagram menggambarkan struktur sistem dari segi pendefinisian kelas-kelas yang akan dibuat untuk membangun sistem. Class diagram yang diusulkan sebagai berikut: 


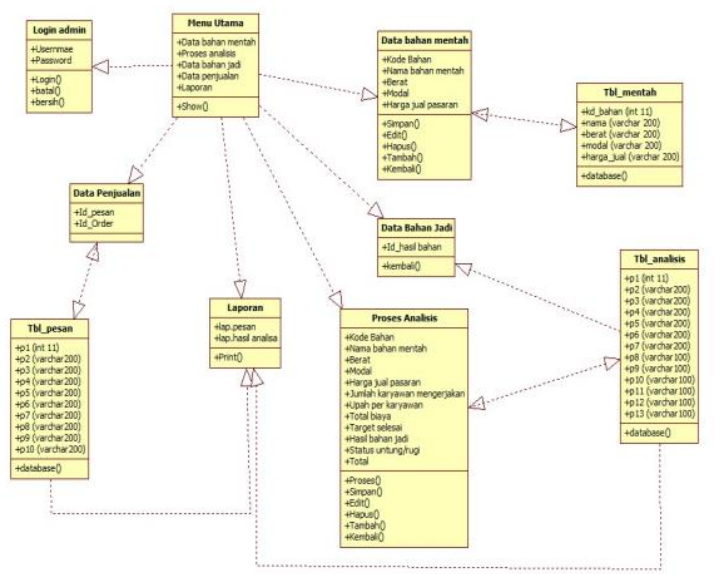

Gambar 4.2 Class Diagram

\section{E. Activity Diagram}

Activity diagram menggambarkan aktivitas dari sebuah sistem atau proses bisnis atau menu yang ada pada perangkat lunak. Adapun activity diagram yang diusulkan adalah sebagai berikut:

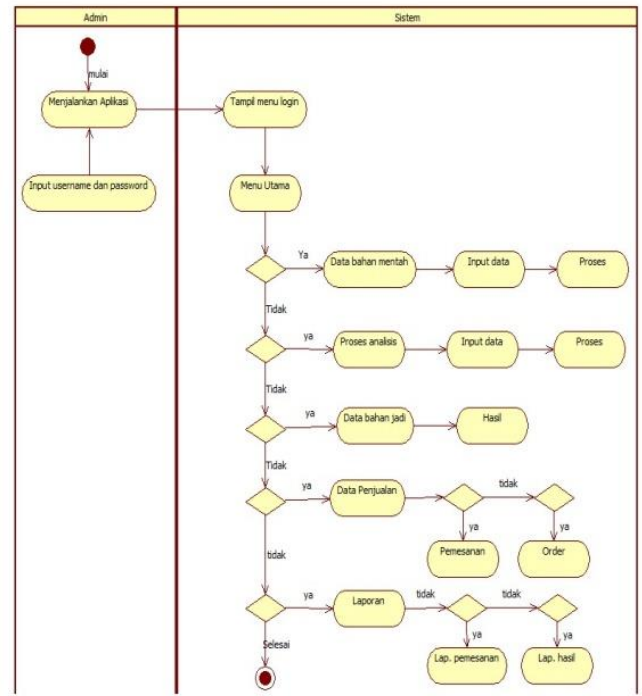

Gambar 4.3 Activity Diagram

\section{F. Component Diagram}

Component diagram menggambarkan struktur dan hubungan antar komponen piranti lunak, termasuk ketergantungan (dependency) di antaranya. Komponen piranti lunak adalah modul berisi code, baik berisi source code maupun binary code, baik library maupun executable, baik yang muncul pada compile time, link time, maupun run time.

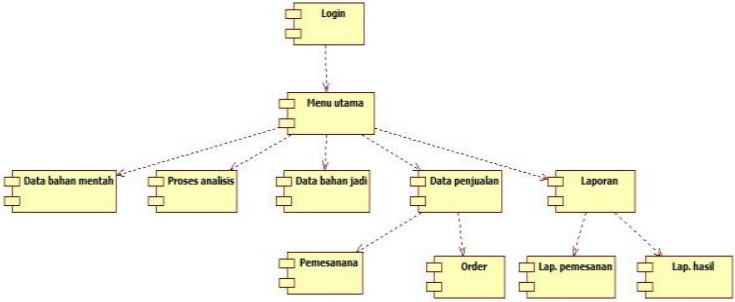

Gambar 4.9 Component Diagram

G. Implementasi Tampilan Program

Tampilan menu login admin

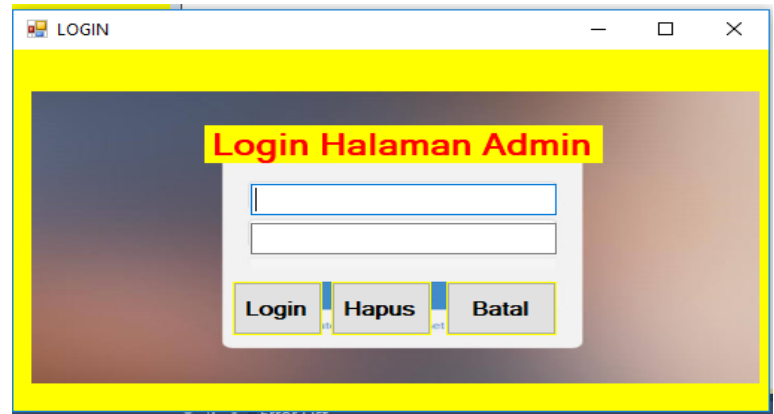

Gambar 4.18 Halaman Login

Tampilan menu utama

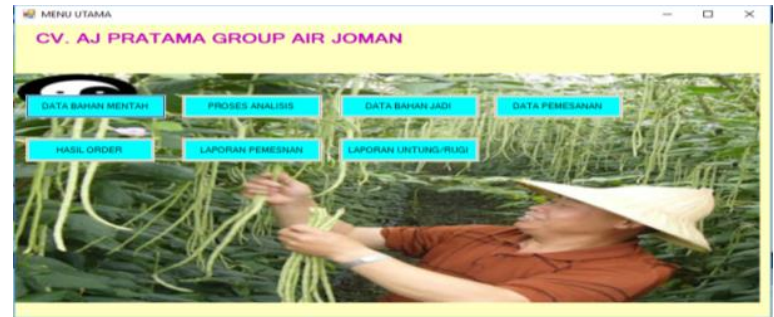

Gambar 4.19 Halaman Menu Utama

Tampilan menu data bahan mentah

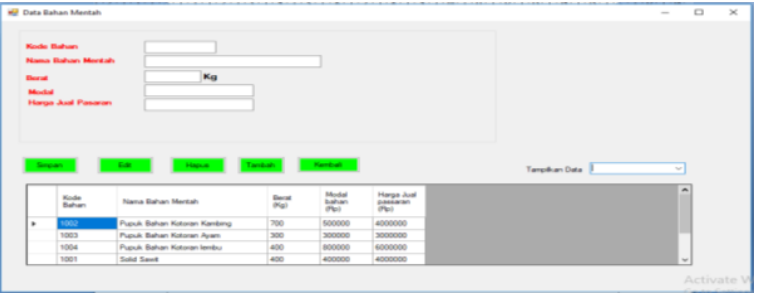

Gambar 4.20 Tampilan Menu Data Bahan Mentah 
Tampilan menu proses analisis

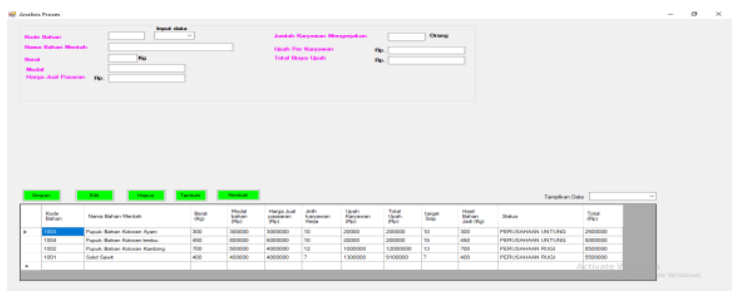

Gambar 4.21 Tampilan Menu Proses Analisis

Tampilan menu proses analisis data

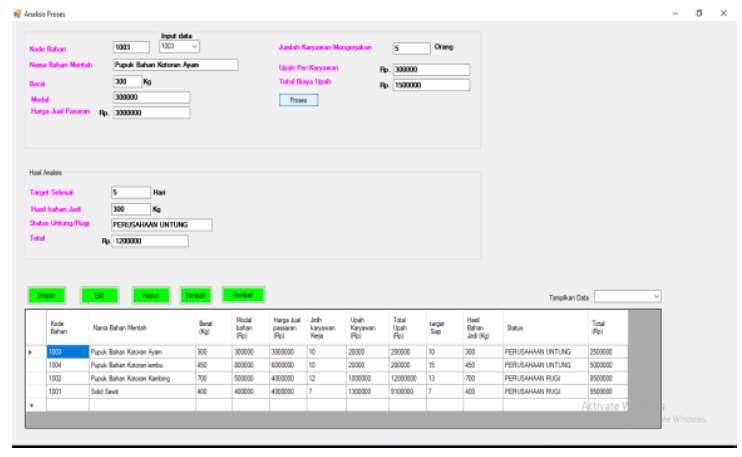

Gambar 4.22 Tampilan Menu Proses Analisis Data

Tampilan menu data bahan jadi

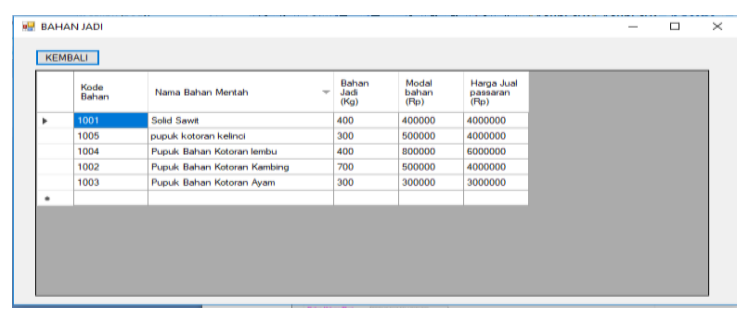

Gambar 4.23 Tampilan Menu Data Bahan jadi

Tampilan menu data penjualan

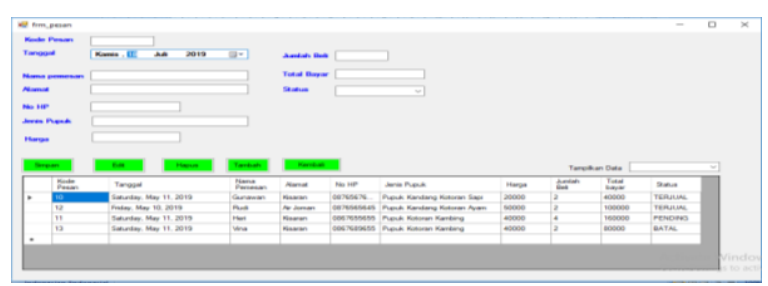

Gambar 4.24 Tampilan Menu Data Pemesanan

\section{TAMPILAN MENU ORDER}

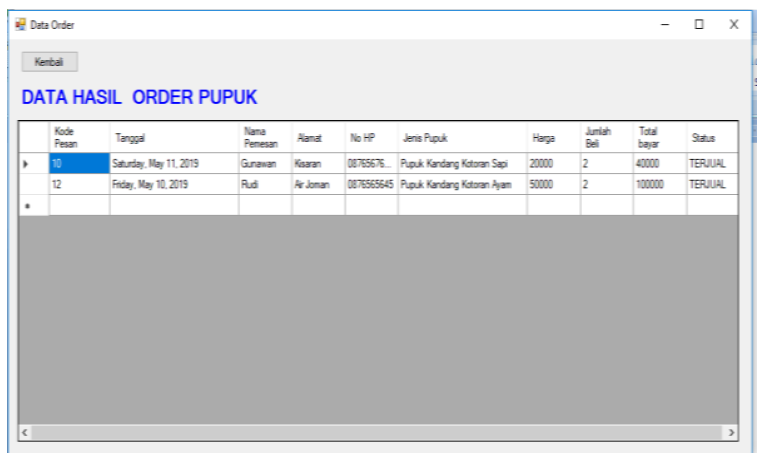

Gambar 4.25 Tampilan Menu Order

Tampilan Menu Laporan

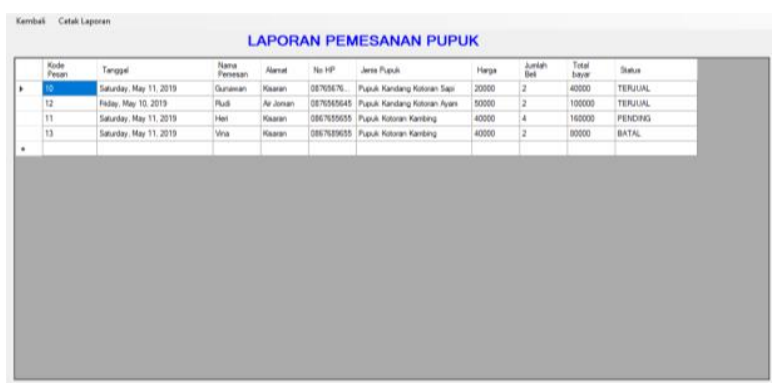

Gambar 4.26 Tampilan Menu Laporan Pemesanan

Tampilan menu laporan pendapatan

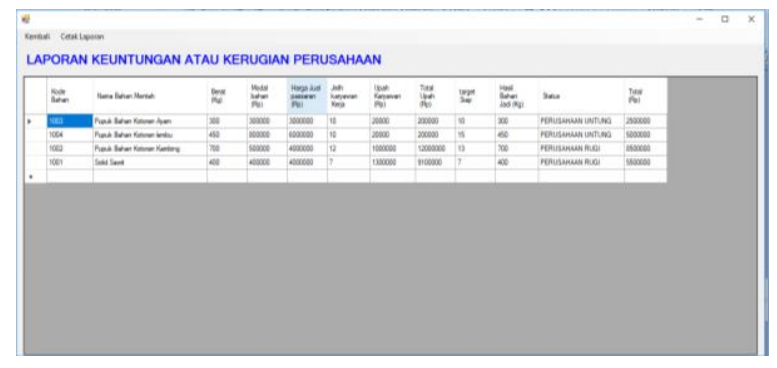

Gambar 4.27 Tampilan Menu Laporan Pendapatan

\section{PENUTUP}

A. Kesimpulan

Setelah menyelesaikan dan menjaklankan aplikasi ini, dapat disimpulkan bahwa:

1. Aplikasi ini dapat digunakan untuk menggantikan metode yang lama yang masih manual.

2. Aplikasi yang dirancang oleh penulis ini telah dapat digunakan sebagai alat untuk menentukan stok bahan baku ataupun untuk menghitung laba yang di dapat oleh pabrik atau perusahaan yang menggunakannya. 
3. Metode Just In Time (JIT) digunakan untuk menghitung laba ataupun menentukan besaraan stok bahan baku dan bahan jadi.

B. Keterbatasan

Terdapat keterbatasan dalam aplikasi ini, diharapkan:

1. Menu pilahan atau menu utamanya dirancang sangat sederhana dan sedikit. Diharapkan ada penambahan agar bisa lebih lengkap dan dilakukan penelitian lebih lanjut.

2. Tampilan yang dirancang dalam aplikasi ini masih sederhana, sehingga diharapkan dapat dikembangkan agar tampilannya lebih menarik lagi.

3. Hendaknya aplikasi ini dapat dikembangkan lebih lanjut agar lebih baik dan berguna dalam mengambil keputusan yang tepat dan lebih akurat.

\section{DAFTAR PUSTAKA}

[1] Azahar Madianto, Dzulkirom.AR, Dwi Armanto, (2016), "Analisis Implementasi Sistem Just In Time (JIT) pada Persediaan Bahan Baku untuk Memenuhi Kebutuhan Produksi”. Jurnal Administrasi Bisnis". Universitas Brawijaya Malang. Vol 38, No. 1, September 2016.

[2] Deni Mahdiana, (2011), "Analisa dan Perancangan Sistem Informasi Pengadaan Barang dengan Metode Berorientasi Obyek Study Kasus PT. Liga Indonesia". Jurnal Telematika MKOM". Universitas Budi Luhur. Vol 3, No. 2, September 2011.

[3] Dewi Sawitri, 2015. Perancangan Sistem Informasi Manajemen Persediaan Barang Electrolux Authorized Service CV. Momentum Teknik”. 2015. Universitas Gunadarma.

[4] Dwi Prianti, Siska Iriani, (2013), "Sistem Informasi Data Penduduk pada Desa Bodoharjo Kecamatan Ngadirojo Kabupaten Pacitan". Indonesian Journal On Network and Security (IJNS)". Vol 2, No. 4, Oktober 2013.

[5] Fauzi Rahman, Santoso, (2015), "Aplikasi Pemesanan Undangan Online". Jurnal Sains dan Informatika". Politeknik Negeri Tanah Laut. Vol 1, No. 2, November 2015.

[6] Nurullah, 2012. "Perancangan dan Pembuatan Sistem Informasi Akuntansi pada $\quad$ STMIK U'BUDIYAH

[7] Rohayah, 2016. "Analisis Perlakuan Akuntansi Persediaan pada PT. TongFong Indonesia".Universitas Maritim Raja Ali Haji.

[8] Winda Aprianti, Umi Maliha, (2016), "Sistem Informasi Kepadatan Penduduk
Kelurahan atau Desa Study Kasus pada Kecamatan Bati-Bati Kabupaten Tanah Laut". Politeknik Negeri Tanah Laut". Vol 2, No. 1, Juni 2016. 